\title{
InfoNorth
}

\section{Frederick Cook and the Forgotten Pole}

\section{by Randall J. Osczevski}

I v 1909, Dr. Frederick A. Cook created a worldwide sensation when he announced that he had reached the North Pole. Although the debate about Cook's expedition still rages in some circles and new books are published on the controversy each decade, most polar historians and editors of encyclopedias agree that Cook never went out of sight of land, let alone to the North Pole. Robert E. Peary is generally credited with being first at the North Pole, although even his claim has detractors (Herbert, 1989).

Before Peary could be acknowledged as the discoverer of the North Pole, he had to wrestle that honour away from Cook, who had won the hearts of the public. In one of Peary's first attacks, the Peary Arctic Club (PAC) issued a press release that included a map showing what Peary said was Cook's actual route (Fig. 1). Cook's companions on the journey, two young Polar Eskimos from Greenland named Etukishook and Ahpellah, had marked their route on a map for Peary when his ship had stopped at Etah, Greenland, on its way back from the edge of the Arctic Ocean. The PAC map showed that instead of going to the North Pole, Cook had gone only a short distance to the northwest on the Arctic Ocean before turning back. He reached land only a few kilometres west of where he left it.

Cook and his party could have returned to Greenland along their outward route up Nansen Sound. According to Peary, however, they went south instead of east, following the west coast of Axel Heiberg Island, and then crossed the ice westward to a previously unknown island, which Etukishook sketched on Peary's map. On the way south, they stopped to hunt at a couple of places on the east coast of Amund Ringnes Island, but they had little success and were forced to kill some of the dogs. Eventually, they crossed the southwest corner of Ellesmere Island to Jones Sound and Devon Island, where they spent the summer and much of the winter. This curious diversion added almost a year to the time they were away from their base in Greenland, to no apparent purpose.

The Dr. Frederick A. Cook Society, which was founded in 1956 to gain official recognition for Cook's accomplishments, takes the position that Peary and his backers invented the route marked on the PAC map to discredit Cook so that Peary could take on the mantle of the discoverer of the North Pole. Ted Heckathorne, a very active member of the Society, rejects the PAC route for two reasons. First, had Cook followed that route, he would have made several geographical discoveries that he could easily have claimed, but he did not do so. Second, following that route would have been "totally irrational":

Based upon what was known in 1908, [the PAC route] would have entailed serious physical risks, possible starvation and travel over an unfamiliar route that had been previously explored by others. Why would Cook be foolish enough to choose that route when he could return over his outward route with plentiful food and relatively easy travel? (Heckathorne, 1998:14)

Why indeed? Another investigator who believed this route had been concocted by Peary described this diversion to Jones Sound as "insane" and concluded that it would take a Jules Verne to come up with a story to explain it (Hall, 1917).

Cook's (1913) version of events was quite different from Peary's. He said that unexpected westward ice drift had carried them astray on their return from the North Pole, and that open water had cut them off from their planned return route down Nansen Sound. There actually is a slow westward drift of ice in the region through which Cook claimed to have passed, but that was not known at the time. Cook claimed they'd been forced to go to Jones Sound in search of a whaling ship because the drifting ice in the archipelago (in June!) had taken them too far to the south. Cook did not mention the new island or admit that they had travelled down the east coast of Amund Ringnes Island. In his version, they travelled down the west coast, along Hassel Sound.

Impressive confirmation of one aspect of Peary's version of Cook's route came seven years later, when Ahpellah and Etukishook's new island was officially "discovered" by the Canadian explorer Vilhjalmur Stefansson. It was later named Meighen Island after a former prime minister. Etukishook's quick sketch of Meighen Island is a better representation than the map laboriously drawn by Stefansson. Etukishook not only got its shape and size right, but he charted it surprisingly accurately with respect to the lands south of it.

Stefansson maintained that Cook's failure to claim discovery of Meighen Island was one of the great mysteries of polar exploration. He felt that Cook could easily have worked it into his fictional account of reaching the 


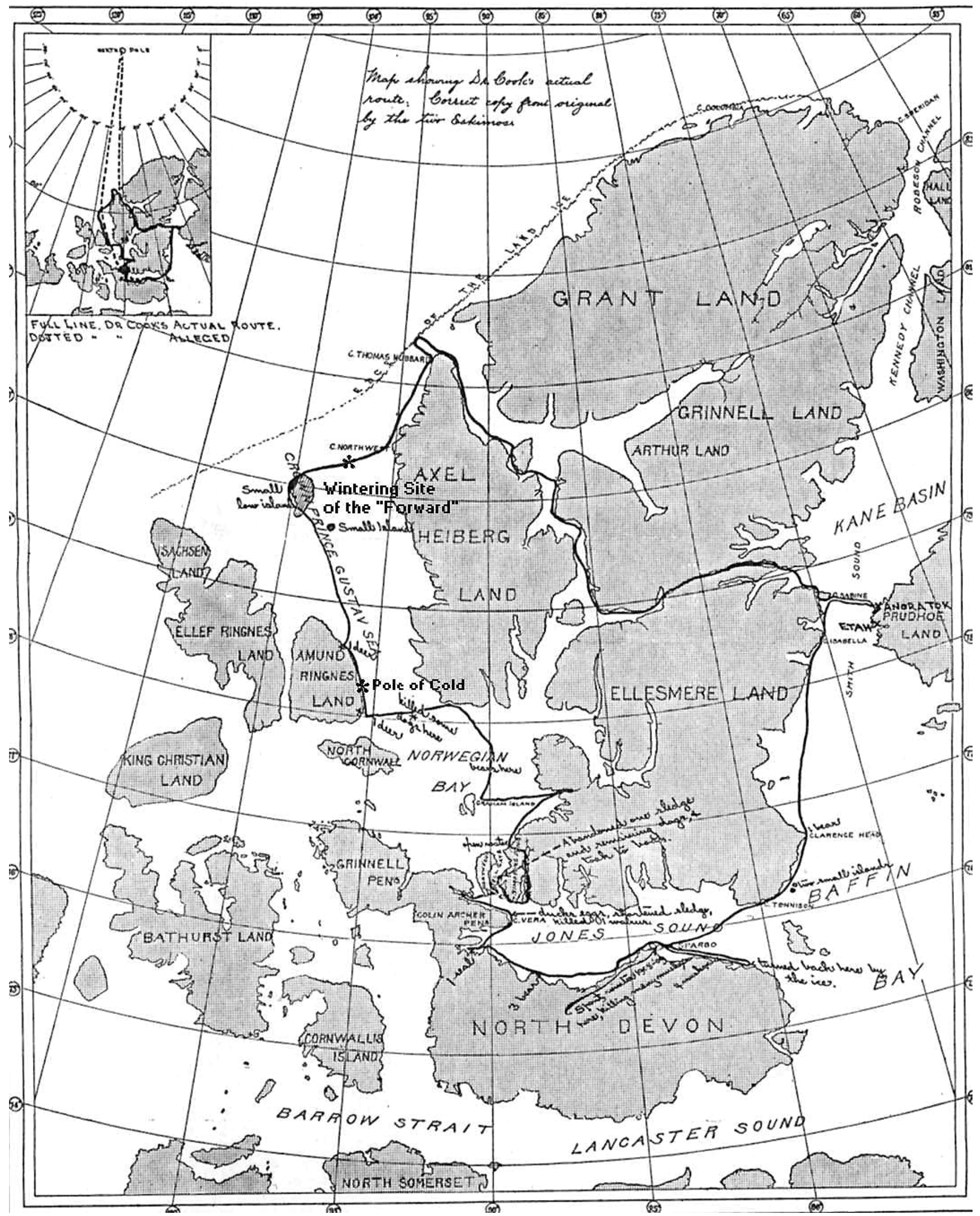

FIG. 1. The Peary Arctic Club map of October 1909. Courtesy of the U.S. Library of Congress. The locations of the "Pole of Cold" and the wintering site of the "Forward" were added by the author, from coordinates given by Jules Verne. 
North Pole and was mystified that he did not, for there seemed to be no reason to cover it up (Stefansson, 1938). In 1990, I suggested that Cook might not have mentioned the island if he had left on it a message in a cairn bearing a date that would contradict the story he later constructed about reaching the North Pole (Osczevski, 1990). However, I now think this is unlikely, for Cook seems to have had a policy of not leaving messages along his route, and previously, in the Antarctic, he had ridiculed the practice of raising the flag and claiming new land (Cook, 1980).

For those who accept the Peary version of Cook's travels, there are indeed several intriguing mysteries to explain. Why did Cook risk an unnecessary journey that added hundreds of kilometres and nearly a year to his expedition? Why did he lie about where he'd travelled after returning from the Arctic Ocean, when it seemed there was no reason to lead inquiry away from this area? And why did he fail to claim discovery of at least one large, previously unknown island that his companions charted seven years before it was officially discovered? Was there something about these places that attracted Dr. Cook and required this cover-up?

In the last few years I have explored a simple but surprising explanation for Cook's apparently aimless wanderings. I have unearthed an arcane goal that might have been Cook's objective on the east coast of Amund Ringnes Island. It is another pole, one that the world has forgotten. Perhaps Cook saw it as a consolation prize after failing to reach the North Pole. I believe that this forgotten pole is the key to understanding the enigmatic Dr. Cook. What follows is a brief account of my journey towards what I hope is true understanding, and not delusion.

\section{MY JOURNEY TO THE CENTRE OF DR. COOK}

I took my first step on the cold trail of Dr. Cook in 1959 at a Saturday afternoon movie, although I wasn't aware of it at the time. Forty years later, I bought a copy of the movie on videotape. It was 20th Century Fox's version of the 1864 Jules Verne adventure classic, Journey to the Centre of the Earth. While watching the movie with my family in 1999, I was reminded of the race for the North Pole. There were even a few lines of dialogue added by the scriptwriters that seemed to be direct references to the polar controversy. The film inspired me to read Jules Verne's book (Verne, n.d.a), where I found several interesting parallels between Dr. Cook and Verne's hero, Professor Otto Liedenbrock, and between their expeditions:

- Professor Liedenbrock was a German who lived and taught in Hamburg, Germany. Cook's German parents came from a small town outside Hamburg, suggesting that there might be a greater than normal chance that this book had been part of Cook's childhood.

- The professor took his young German nephew Axel with him on the expedition. Cook selected a young
German named Rudolphe Franke from the crew of the expedition ship to stay with him in Greenland over the winter and to travel with him on the first leg of the journey north.

- In the interior of the Earth, far from the shore of a subterranean sea, Professor Liedenbrock discovered an island, which he named Axel Island after his nephew. After the party left Axel Island, an electrical storm re-magnetized the professor's compass so that it pointed south instead of north. Cook left land on his polar attempt at a real "Axel Island," Axel Heiberg Island, where his compass also pointed south instead of north: not because it was faulty, but because he was directly north of the magnetic pole. Might this be the inspiration for the unorthodox route Cook used in his attempt on the North Pole?

- Like Cook's story of piercing "the Boreal Center"a term Cook invented-Liedenbrock's account of his journey towards the Earth's centre was highly controversial: "The leading newspapers extracted the most interesting passages, which were commented upon, picked to pieces, discussed, attacked, and defended with equal enthusiasm and determination, both by believers and skeptics" (Verne, n.d.a:254).

- Professor Liedenbrock was said to be: "modest notwithstanding his glory, and he was all the more famous for his humility" (Verne, n.d.a:253). Frederick Cook was also famous for being modest and selfeffacing. It was part of his considerable charm.

- Professor Liedenbrock "enjoyed during his lifetime the glory he had deservedly won;" and the "honour of an offer from Mr. Barnum, to exhibit him... in all of the principal cities in the United States!" (Verne, n.d.a:254). For Cook, the glory did not last, but he did tour the United States, not with P. T. Barnum of course, but with Chautauqua.

- "From that day forth, the Professor became the most glorious of savants...the illustrious Otto Liedenbrock, corresponding member of all the scientific, geographical and mineralogical societies of the civilized world..." (Verne, n.d.a:256). What more could a man of science want? Had he read Verne's book, as I was beginning to suspect, Cook might have been prepared for the controversy that followed his polar claim. He might also have expected that eventually he would share the same reward as Liedenbrock, who'd had no more proof of his fantastic claim than Cook had of his. Perhaps this was what Cook sought: not financial gain, but recognition.

Intrigued by these parallels, I explored some of Verne's other stories to see if they might also be reflected in Cook's account. 


\section{ICE ISLANDS AND THE FUR COUNTRY}

One of the most heralded of Cook's "discoveries" is his description of something that sounds very much like an ice island (Koenig et al., 1952). He said he crossed this "glacial" or "submerged" island near $88^{\circ} \mathrm{N}$ latitude. Ice islands are massive ice floes that may be many square kilometres in extent and $50 \mathrm{~m}$ thick. They form in the vicinity of land over decades or centuries and then break off to drift around in the Arctic Ocean, sometimes for many years.

Cook saw and described the raw material for such islands in the mouth of Nansen Sound (Jeffries et al., 1992) and possibly in the Sverdrup Channel between Meighen Island and Axel Heiberg Island, where a massive plug of old ice with dimensions similar to those of Cook's glacial island sometimes forms (Jeffers et al., 2001). It sometimes has the typical wavy surface of an ice island, just as Cook described his "glacial island" (Serson, 1974). Cook could not determine whether this ice was afloat or resting on submerged land. If the ice he described was actually the ice plug in the Sverdrup Channel, his doubt about whether or not it was a permanent feature connecting Meighen Island to Axel Heiberg Island might have prevented him from incorporating Meighen Island into his story of reaching the North Pole. If some subsequent explorer proved that the new land was permanently connected, there would have been no reason for Cook not taking the easy route back to Greenland, up Nansen Sound.

It is highly unlikely that Cook would have seen an ice island break away from the land and drift towards the North Pole, for such events are rare and the currents would be more likely to carry it to the south. It is also unlikely that he could have gotten the idea by encountering an ice island on the polar pack, even if he had actually travelled a long distance on it. At the end of a modern polar expedition, a group of explorers searched anxiously for the ice island ARLIS II so that they could be rescued. Although it rose high above the sea ice, they were able to see it only when it was $1.5 \mathrm{~km}$ away. Even from that short distance, in sunshine, it was noticeable only because it bore a brightly coloured aircraft (Staib, 1965).

So where did Cook get the idea that such a thing might exist in the Arctic Ocean? Some Cook supporters have maintained that Cook couldn't have invented an ice island or its drift path, so he must have seen one far from land, in the area where ice islands have since been noted (Horwood, 1977; Cook, 1999). However, this conclusion underestimates Cook and ignores the possibility that someone else might have already invented the concept. In fact, someone else had; when Cook was a boy, Jules Verne published a novel about an ice island.

The Fur Country or Seventy Degrees North Latitude (Verne, 1874) is a fictional history of a newly established Hudson Bay Company fur trading post on Cape Bathurst in the Western Arctic of Canada. During the winter, the occupants of the post become aware that the point on which they have built their trading post is not land at all, but very old, thick ice covered with soil. An earthquake causes the ice to break away from the continent and drift uncontrollably westward, to join ocean currents that will take them either north into the Arctic Ocean or south through the Bering Strait, causing their "island" to melt as it is carried south. Had Cook read this story, this description, plus his own observations of very old landfast ice, might well have suggested the possibility that a moving island of ice might exist in the Arctic Ocean. One of Verne's characters even suggested that their ice island, in the proper ocean current, could become a conveyance for reaching the North Pole.

\section{THE ENGLISH AT THE NORTH POLE}

My search for fictional parallels with Cook's expedition moved to Verne's two-part novel, The English at the North Pole, first published in 1864, and its sequel, The Ice Desert, first published in 1866 . Verne's polar adventure involves an expedition to the North Pole, a ship called the Forward, and a wintering at the "pole of cold," which was also mentioned in The Fur Country.

The presumably fictional pole, "the Frozen Pole" in this English translation (Verne, n.d.b), first appears during a discussion of the possible existence of an open polar sea. Its position was first given in the text (Verne, n.d.b) as $78^{\circ}$ $\mathrm{N}, 97^{\circ} \mathrm{W}$ - two degrees west of its location in The Fur Country. On a map (Fig. 2) in a reprint of the original French version (Verne, 1978), the "Pôle du Froid" (i.e., Pole of Cold) is plotted at approximately $79^{\circ} \mathrm{N}, 98^{\circ} \mathrm{W}$.

It is interesting to compare Dr. Cook and one of the main characters of this story, Dr. Clawbonny. Both men had an extraordinary knack for making friends: "Clawbonny's character had the same effect on everybody; friends grew up around him like corn in the sun" (Verne, n.d.b:266).

Dr. Clawbonny might well have been a good role model for a boy growing up in the last half of the 19th century, especially one like Cook who at the age of five had lost his father, also a doctor.

Dr. Clawbonny was a doctor, and a good one, though practising little. At the age of twenty-five he was an ordinary practitioner; at the age of forty he was a savant, well known in the town; he was an influential member of all the literary and scientific institutions in Liverpool. His fortune allowed him to distribute counsels, which were none the worse for being gratuitous; beloved as a man eminently loveable must always be, he had never wronged anyone, not even himself; lively and talkative, he carried his heart in his hand, and put his hand into that of everybody. (Verne, n.d.b:22)

Peary's strongest supporter, Vilhjalmur Stefansson, was aware of Cook's effect on people and pointedly 


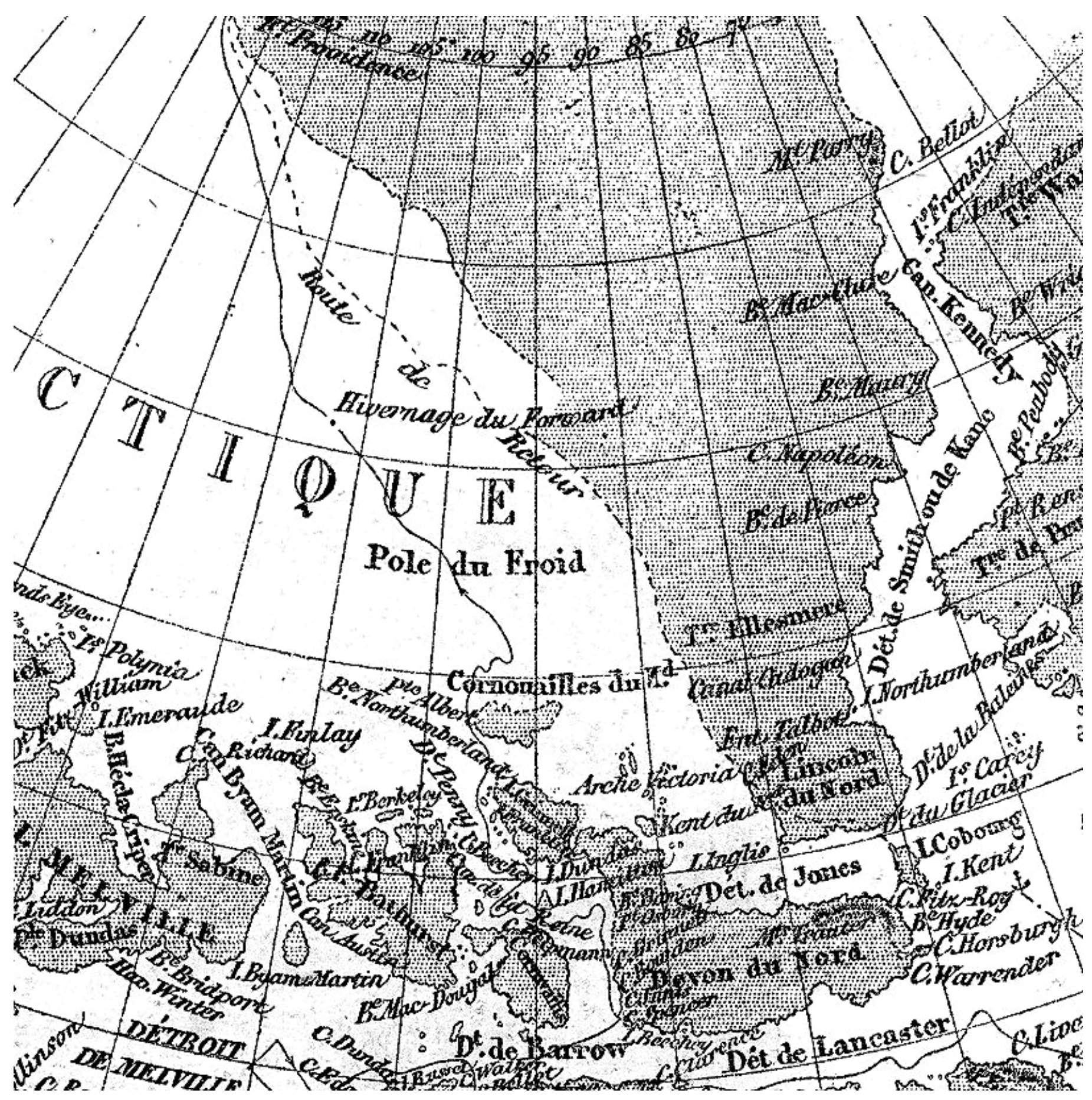

FIG. 2. Part of the map drawn by Jules Verne to illustrate The English at the North Pole and its sequel, The Ice Desert (Verne, 1978).

avoided meeting him because he did not want to risk being influenced by the man's powerful charisma. He admitted: "No one who knew Cook disliked him. Many loved him" (Weems, 1961:xiii).

As Verne's fictional expedition made its way north, Dr. Clawbonny became concerned by the captain's refusal to leave messages along their route to guide potential rescuers. Captain Hatteras explained that competitors might find them and gain some advantage. Cook seems to have had a similar policy.
In 1897, Cook was a member of an expedition that was wintering in the Antarctic when the ship, the Belgica, became trapped in the ice. One of Cook's most acclaimed actions during this expedition echoes an order given by the fictional Captain Hatteras when his ship, the Forward, was beset by ice. Hatteras commanded that it be "surrounded by a belt of hammocks, filled with air, so as to shield her from the thick of the damage" (Verne, n.d.b:163). Cook used a similar tactic to protect the Belgica. Instead of inflated hammocks, 
Cook used mats of penguin skins and was lauded for his ingenuity (Cook, 1980).

In mid-September, the crew of the Forward prepared to winter "out of sight of land at latitude $78^{\circ} 15^{\prime} \mathrm{N}$, longitude $95^{\circ} 35^{\prime} \mathrm{W}$ in the midst of the unknown sea where geographers have placed the Northern Pole" (Verne, n.d.b:164). While these coordinates placed the Frozen Pole in a blank space on any 19th-century map Verne might have had, we now know that it is not in the midst of an "unknown sea," but on land, near the east coast of Amund Ringnes Island.

Dr. Clawbonny confirmed the pole's precise location: "We were in latitude $78^{\circ} 15^{\prime}$ by longitude $95^{\circ} 35^{\prime}$; exactly at the Frozen Pole" (Verne, n.d.b:188).

During the winter, the Forward drifted northward and westward with the ice, coming to rest at latitude $80^{\circ} 15^{\prime} \mathrm{N}$ and $97^{\circ} 35^{\prime} \mathrm{W}$ longitude. On a modern map, this is at the mouth of the Sverdrup Channel, which separates Axel Heiberg Island from Meighen Island. When these coordinates are plotted on Figure 1, the location falls on Cook's route.

Verne's fictional expedition spent much of the winter at that location; there too the Forward was lost-burned and abandoned by a mutinous crew. The small party that was left, which included the doctor and the captain, went on from there over relatively smooth ice to reach the North Pole, discovering new land to the north. Might Cook have visited this spot in the hope of finding the good ice conditions of Verne's story?

When the Frozen Pole is plotted on Peary's map, as I have done, it too is on Cook's route. Another coincidence? If we accept that the Frozen Pole was Cook's goal on eastern Amund Ringnes Island, the wandering route marked on Peary's map no longer seems aimless.

\section{A "SMOKING GUN"}

In September of 1999, my son and I drove down from Canada to the area of New York State where Cook had spent his early years. I wanted to see if I could find some hint that Cook had read Verne. Cook said that he had read few works of fiction. The only books he mentioned by name were Dr. Elisha Kent Kane's narratives of his Arctic expeditions. I knew it was a long shot, but I planned to scour secondhand bookstores in the area and to visit the Cook display and library at the Sullivan County Museum in Hurleyville, New York, to see if they had any books by Jules Verne in their collection of Cook memorabilia.

The Sullivan County Museum was in a large converted house in a little out-of-the-way village in the woods of New York State near the Catskill Mountains. We found the Cook display room on the second floor, near the top of the staircase. The office and library of the Dr. Frederick A. Cook Society were closed, but the display room was open. Just inside the entrance to the room was a small glass display cabinet, but we passed it by in favour of a large lighted display of books. To my disappointment, the books in the lighted display were all on the polar controversy; there were none that Cook might have owned before 1909.

We examined every case and every artefact in the room without finding any hint of Verne's works. As we were leaving, I noticed a small model sledge on the bottom shelf of the small glass case that we had bypassed on the way in. I was interested because I have built several sledges on the Inuit pattern. When I knelt down to look it, I noticed that there was a book beside it on the shelf: Kane's Arctic Expeditions, Volume I. Volume II was on the top shelf, or perhaps it was the other way around. Cook credited these two books with stimulating his interest in the Arctic, so I was not surprised to find them on display. Perhaps they were even Cook's original copies. There were no information cards related to them, but Frederick Cook's brother had donated some of the other items in the case.

I then noticed another book on the top shelf. The lighting was dim and the binding was very dark so I had to bend close to the glass. The first thing I was able to read on the cover was the author's name, Jules Verne. A few seconds later, with growing excitement, I was able to make out the title: The English at the North Pole. I could hardly believe my eyes.

Verne seems to have based much of The English At the North Pole and its sequel The Ice Desert on the Arctic experiences of Dr. Kane (Riffenburgh, 1991; Sawin, 1997). This might explain not only Cook's interest in the story, but why a book containing what could be the "blueprint" of a major part of his last and most controversial polar expedition is on display in the museum. Of course, there might be a less prosaic explanation-it might be an intentional clue, donated or displayed by someone who suspected the Verne connection but dared not expose it.

\section{DREAMS AND HEROES}

If Cook was influenced by the writings of Jules Verne, he was not the first, nor would he be the last. For example, Fridtjof Nansen named his polar ship "Fram," which is Norwegian for "Forward"; Andrée, the Swedish balloonist, was inspired by Jules Verne to attempt to reach the North Pole, with tragic results (Capelotti, 1999); and Sir George Hubert Wilkins, Lincoln Ellsworth, and Simon Lake made the first under-ice attempt on the North Pole in a vessel they named "Nautilus" after the submarine in Verne's Twenty Thousand Leagues Under the Sea. Lake began building submarines as a child, shortly after reading Verne's book (Wilkins, 1931); it became his career.

While pondering the origins of his exploration dreams, Nansen (1898:373), the dean of polar explorers at the end of the 19th century, admitted: "I was simply a child yearning for a great adventure out in the unknown, who had dreamed of it so long that at last I believed it really awaited me."

Cook's conquest of the Frozen Pole may have had a similar origin in childhood fantasy. In his unpublished 
writings about prison reform, "Out of the Jungle," Cook wrote:

Most boys early develop an all-absorbing ambition. If the mind and body is [sic] put to work on the path fired by this ambition, there will be developed a capacity for a prodigious amount of work; and this rule follows along all through the successive stages of man's existence, for the adult is always a boy. [Emphasis added] (Bryce, 1997:949)

A casual remark Cook made on being asked about his feelings on arriving at the "North Pole" seems to support this inference. He admitted that he had been disappointed when he reached the spot and mused: "Man is a child dreaming of prodigies" (Bryce, 1997:365).

We should not be surprised if a fatherless boy living in relative poverty in the 19th century found strong male role models in exploration narratives, both real and fictional. Cook overcame the poverty that dogged his youth to become a physician, but clearly it wasn't enough. His motive for hoaxing the world was clearly not financial, for he turned down opportunities of making a vast fortune from his story. Perhaps the boy he had once been would only be proud of the man he had become if that man were as celebrated as his boyhood heroes.

\section{CONCLUSION}

I believe that Cook's movements in the late winter of 1908 were related to his interest in Verne's fictional polar expedition and that his account of reaching the North Pole is based on his conquest of Verne's fictional pole. After returning to land at Cape Thomas Hubbard, he had time to kill and the means to sledge south to Verne's "Pole of Cold," so he went to experience Verne's landscape firsthand, just as modern tourists make pilgrimages to Prince Edward Island each year to see the farmhouse they read about as children in the "Anne of Green Gables" stories.

More than a tourist expedition, however, Cook's trip was research for his fictional story of reaching the North Pole. Anyone familiar with the scandal about Cook's faked first climb of Mount McKinley will recognize the pattern: just as one easy mountain peak was as good as another that was out of reach, the "Frozen Pole" was as good as the ultimate prize.

One contemporary anonymous review of a new Verne book, probably written by Verne himself, stated: "M. Jules Verne... knows how to link fiction to reality in proportions so exact that one does not know where one begins and the other leaves off" (Evans, 1996:178). Frederick Cook was clearly from the same school of writers. The author of a narrative of an expedition to this lesser pole, who claimed the much greater prize, would surely have wished to avoid comparison with Verne's fictional expedition. To that end, he might have sacrificed any minor discoveries made on that route. He needn't have bothered, as it turned out. Although Cook's actual route was widely published by Peary in 1909, the Verne connection was not suspected for another 90 years.

\section{REFERENCES}

BRYCE, R. 1997. Cook and Peary: The polar controversy resolved. Mechanicsburg, Pennsylvania: Stackpole Books.

CAPELOTTI, P. 1999. By airship to the North Pole: An archaeology of human exploration. New Brunswick, New Jersey: Rutgers University Press.

COOK, F. 1913. My attainment of the Pole. New York: Mitchell Kennerley.

. 1980. Through the First Antarctic Night 1898-1899.

Montreal: McGill-Queen's University Press.

COOK, S. 1999. Reflections on the Polar "Noose of Laurels." Polar Priorities 19:13-37.

EVANS, A. 1996. Literary intertexts in Jules Verne's Voyages Extraordinaires, Science-Fiction Studies 23(2): \#69:171-187 (http://jv.gilead.org.il/evans/literary.html)

HALL, T.F. 1917. Has the North Pole been discovered? Boston: Richard G. Badger.

HECKATHORNE, T. 1998. Dr. Frederick Cook's 1908 journey: A 1998 Arctic field investigation. Polar Priorities 18:4-15.

HERBERT, W. 1989. The noose of laurels. London: Hodder and Stoughton.

HORWOOD, H.A. 1977. Bartlett: The great Canadian explorer. Garden City, New York: Doubleday.

JEFFERS, S., AGNEW, T., TAYLOR ALT, B., DE AUBREY, R., and McCOURT, S. 2001. Investigating the anomalous sea-ice conditions in the Canadian High Arctic (Queen Elizabeth Islands) during summer 1998. Annals of Glaciology 33:507-512.

JEFFRIES, M., REYNOLDS, G., and MILLER J. 1992. First Landsat multi-spectral scanner images of the Canadian Arctic north of $80^{\circ} \mathrm{N}$. Polar Record 28(164):1-6.

KOENIG, L., GREENAWAY, K., DUNBAR, M., and HATTERSLEY-SMITH, G. 1952. Arctic ice islands. Arctic 5(1):67-103.

NANSEN, F. 1898. Farthest North, Vol. I. London: George Newnes.

OSCZEVSKI, R.J. 1990. Frederick Cook's polar journey: A reconstruction. Polar Record 25(158):225-232.

RIFFENBURGH, B. 1991. Jules Verne and the conquest of the Polar regions. Polar Record 27(162):237-240.

SAWIN, M.H. 1997. Raising Kane: The making of a hero, the marketing of a celebrity. M.A. Thesis, University of Texas, Austin, Texas.

SERSON, H. 1974. Sverdrup Channel. Technical Note 74-10. Ottawa: Defence Research Establishment.

STAIB, B. 1965. North toward the Pole on skis. National Geographic (February 1965) 127(2):254-281.

STEFANSSON, V. 1938. The problem of Meighen Island. Privately published. Available at the National Library of Canada.

VERNE, J. 1874. The fur country, or seventy degrees north latitude. Boston: J.R. Osgood. (http://www.canadiana.org/ECO/ mtq?doc $=41516$ ) 


\section{$214 \cdot$ INFONORTH}

n.d.a. (1920?) A journey into the interior of the earth. London, Melbourne and Toronto: Ward, Lock \& Co., Ltd.

. n.d.b. (1920?) The English at the North Pole and The Ice Desert. Collins' Illustrated Pocket Classics. London, Glasgow: Collins Clear-Type Press.

1978. Voyages et aventures de Capitaine Hatteras. Paris: J. Hetzel \& Co.

WEEMS, J. 1961. Race for the North Pole. London: Heinemann.
WILKINS, G.H. 1931. Under the North Pole: The Wilkins-Ellsworth Submarine Expedition. New York: Brewer, Warren \& Putnam.

Randall Osczevski, a physicist with the Department of National Defence, has researched the effects of cold on personnel, equipment, and military operations for more than 25 years. He is the primary author of the new formula for calculating wind chill, now in use across Canada and the United States. E-mail: Randall.Osczevski@ddrc-rrdc.gc.ca 